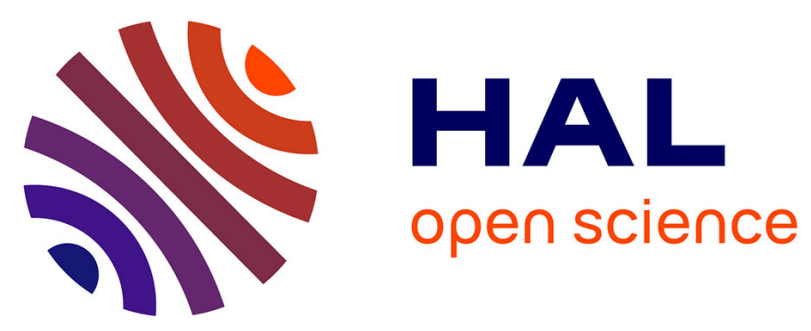

\title{
Seasonality and interindividual variation in mandrill feeding ecology revealed by stable isotope analyses of hair and blood
}

Vicky Oelze, Alice Percher, Gontran Nsi Akoué, Nory El Ksabi, Eric

Willaume, Marie Charpentier

\section{To cite this version:}

Vicky Oelze, Alice Percher, Gontran Nsi Akoué, Nory El Ksabi, Eric Willaume, et al.. Seasonality and interindividual variation in mandrill feeding ecology revealed by stable isotope analyses of hair and blood. American Journal of Primatology, 2020, 10.1002/ajp.23206 . hal-02998461

\section{HAL Id: hal-02998461 \\ https://hal.science/hal-02998461}

Submitted on 14 Nov 2020

HAL is a multi-disciplinary open access archive for the deposit and dissemination of scientific research documents, whether they are published or not. The documents may come from teaching and research institutions in France or abroad, or from public or private research centers.
L'archive ouverte pluridisciplinaire HAL, est destinée au dépôt et à la diffusion de documents scientifiques de niveau recherche, publiés ou non, émanant des établissements d'enseignement et de recherche français ou étrangers, des laboratoires publics ou privés. 


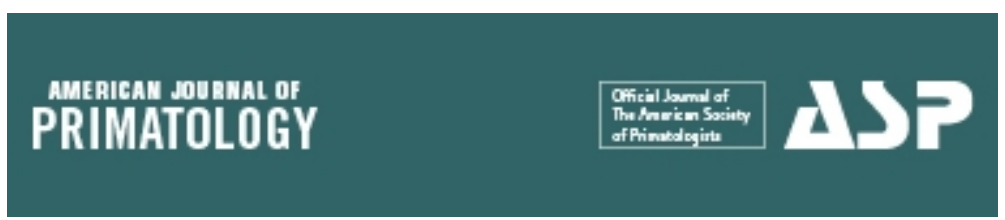

\section{Seasonality and inter-individual variation in mandrill feeding ecology revealed by stable isotope analyses of hair and blood}

\begin{tabular}{|r|l|}
\hline Journal: & American Journal of Primatology \\
\hline Manuscript ID & AJP-20-0069.R2 \\
\hline Wiley - Manuscript type: & Research Article \\
\hline Author: & n/a \\
\hline Complete List of Authors: & $\begin{array}{l}\text { Oelze, Vicky } \\
\text { Percher, Alice } \\
\text { NSI-Akoue, Gontran; University of Sciences and Technology of Masuku, } \\
\text { Department of Biology; University of Sciences and Technology of } \\
\text { Masuku, Department of Biolohy } \\
\text { El Ksabi, Nory } \\
\text { Willaume, Eric; SODEPAL, } \\
\text { Charpentier, Marie; ISEM UMR 5554 }\end{array}$ \\
\hline $\begin{array}{r}\text { Indicate which taxonomic } \\
\text { group was the subject of your } \\
\text { study (select all that apply or } \\
\text { type another option):: }\end{array}$ & Old World monkeys \\
\hline Keywords: & carbon, nitrogen, sex differences, season \\
\hline \multicolumn{2}{|c}{} \\
\hline
\end{tabular}

\section{SCHOLARONE \\ Manuscripts}




\section{Seasonality and inter-individual variation in mandrill feeding ecology} Willaume ${ }^{5}$, Marie JE Charpentier ${ }^{3 *}$

6

${ }^{1}$ Anthropology Department, University of California Santa Cruz, Santa Cruz, USA

$8{ }^{2}$ Department of Primatology, Max Planck Institute for Evolutionary Anthropology,

$9 \quad$ Leipzig, Germany

$10{ }^{3}$ Institut des Sciences de l'Évolution de Montpellier UMR5554, CNRS, IRD, EPHE,

11 Université de Montpellier, Montpellier, France

${ }^{4}$ Université des Sciences et Techniques de Masuku, Franceville, Gabon

${ }^{5}$ SODEPAL, Bakoumba, Gabon

Running head:

Stable isotope analyses in free ranging mandrills

\section{*Corresponding author:}

19 Marie JE Charpentier

20 ISEM UMR5554

21 Place Eugène Bataillon cc065

2234095 Montpellier cedex 05, France

23 Email: marie.charpentier@umontpellier.fr 
25

\section{Abstract}

Mandrills are large bodied, terrestrial forest primates living in particularly large social groups of several hundred individuals. Following these groups in the wild to assess differences in diet over time as well as among individuals is demanding. We here use isotope analyses in blood and hair obtained during repeated captures of 43 identified free-ranging mandrills (Mandrillus sphinx) from Southern Gabon, to test how dietary variation relates to season as well as an individual's age and sex. We measured the stable carbon $\left(\delta^{13} \mathrm{C} \% \mathrm{)}\right)$ and nitrogen $\left(\delta^{15} \mathrm{~N} \%\right)$ isotope ratios in 46 blood and 214 hair section samples as well as from a small selection of mandrill foods $(n=24)$. We found some seasonal isotopic effects, with lower $\delta^{13} \mathrm{C}$ values but higher $\delta^{15} \mathrm{~N}$ values observed during the highly competitive long dry season compared to the fruit-rich long rainy season. Variation in $\delta^{13} \mathrm{C}$ was further predicted by individual age, with higher $\delta^{13} \mathrm{C}$ values generally found in younger individuals suggesting that they may consume more high canopy fruit than older individuals, or that older individuals consume more low canopy foliage. The best predictor for $\delta^{15} \mathrm{~N}$ values was the interaction between age and sex, with mature and reproductively active males revealing the highest $\delta^{15} \mathrm{~N}$ values, despite the observation that males consume substantially less animal food items than females. We interpret high $\delta^{15} \mathrm{~N}$ values in these mature male mandrill blood and hair sections to be the result of nutritional stress associated to intense male-male competition, particularly during mating season. This is the first study showing isotopic evidence for nutritional stress in a free-ranging primate species and may spark further investigations into male mandrill diet and energy balance.

Keywords: carbon, nitrogen, sex differences, season 


\section{$49 \quad$ Research Highlights}

50

- Stable isotope analyses of hair and blood have the potential to provide short and long-term data on how individual diets may shift over the season and with individual traits.

- Dietary patterns differ across seasons, between sexes as well as between young and older mandrills.

- Mature and reproductively active male mandrills showed the highest nitrogen isotope values as a result of nutritional stress possibly associated to intense male-male competition in this species.

- This is the first study showing isotopic evidence for nutritional stress in a freeranging primate species.

61 


\section{Introduction}

Feeding ecology studies are essential to determine an individuals' nutritional and energetic requirements and understand how they translate into different biological and ecological characteristics of a species, such as ranging patterns and socio-sexual behavior (e.g. Chapman and Chapman, 1990, Hohmann et al., 2006, Lambert and Rothman, 2015; McGraw and Daegling, 2012). As with many other animal species, primate sociality highly depends on how food is distributed in the environment. The degree at which individuals use clumped and high energy food resources such as fruits vs. much more dispersed lower energy foods such as foliage gives insights into the evolution of sociality across primate species (Clutton-Brock and Janson, 2012; van Schaik, 1989; Sterck et al., 1997).

Compared to other terrestrial large bodied primates in Africa, such as great apes and baboons, mandrills (Mandrillus sphinx) are clearly understudied in the wild. Our knowledge about mandrill feeding seasonality and competition is limited to a handful of studies conducted in the 1980s (Harrison, 1988; Hoshino et al., 1984; Lahm, 1986; Rogers et al., 1996) as well as much more recent work at a research site in Southern Gabon, the Lékédi Park (Nsi Akoué et al., 2017). Our current understanding is that mandrills are generalist feeders with a clear tendency towards frugivory (Lahm, 1986; Nsi Akoué et al., 2017). During a 17-month behavioral survey, 57 mandrills from the Lékédi population were observed consuming about 150 different plant species (including more than 440 different items), representing $74 \%$ of their diet, along with mushrooms $(<1 \%)$, invertebrates $(6 \%)$ and vertebrates $(<1 \%)$ (Nsi Akoue et al., 2017). Behavioral data additionally suggest that females consumed more faunal food items than males (Nsi Akoue et al., 2017). Among the plant species frequently consumed, 
mandrills relied essentially on $\mathrm{C}_{3}$ plants (e.g. Xylopia aethiopica and Pentaclethra macrophylla), including bamboo, a $\mathrm{C}_{3}$ plant within the grass family Poaceae (e.g. Olyra latifolia, see Nsi Akoué et al., 2017).

While long-term and direct observations of feeding behavior generally constitute the ideal method for determining dietary differences between individuals and across seasons, this requires full habituation and long-term systematic study. In mandrills, direct observations are partially impeded by the fairly large group sizes of several hundred individuals (Abernethy et al., 2002; Harrison, 1988; Rogers et al., 1996). The use of indirect methods to study primate diets are thus a tempting and cost-effective alternative to some, clearly not all, aspects of direct observation. Fecal analysis provides a good overview of what food items are eaten by a primate species over short to long term periods and can be conducted even in unhabituated groups (e.g. Tutin and Fernandez, 1993). However, while fecal analysis is strictly non-invasive and reveals some aspects of what was ingested by the animals the previous day(s), the dietary assessment is potentially biased towards indigestible food items such as fruit seeds, tough foliage and insect chitin (Lahm, 1986) and the method requires repeated sampling over large stretches of time. As an alternative approach, the stable isotopes of carbon $\left(\delta^{13} \mathrm{C}\right)$ and nitrogen $\left(\delta^{15} \mathrm{~N}\right)$ are increasingly used to reconstruct diet and ecological niches of wild animal species with less sampling effort (Crowley, 2012; Crowley et al., 2015). For example, patterns of seasonal dietary overlap and dietary differentiation found in isotope values of hair collected non-invasively from nests of central chimpanzees (Pan troglodytes troglodytes) and lowland gorillas (Gorilla gorilla gorilla) suggested plasticity in the feeding niches of these sympatric apes (Oelze et al., 2014), 
consistent with previous results based on long-term and labor intensive fecal sample collection and analysis (Head et al., 2011).

Stable isotope analysis in samples of body tissue provides estimates of several aspects of the animals' diet in the recent or more distant past (Crowley, 2012; Crowley et al., 2015; Sandberg et al., 2012). Feces and blood are for example turned over by the body fairly rapidly and are related to the diet of the previous days or weeks (Hobson and Clark, 1992). By contrast, hair keratin has a much slower turnover rate of $\sim 1 \mathrm{~cm}$ per month (Tobin, 2005; Fourie et al., 2016), although hair growth rates are yet unknown for most wild primates necessitating to fall back on human hair growth rates as a proxy (Oelze, 2016). In hair, sampling along the growth trajectory from hair root to tip allows for a isotopic time sequence of several consecutive months (O'Connell and Hedges, 1999; Schwertl et al., 2003; Oelze, 2016). The use of sequential hair isotope analysis has shown to be particularly useful to investigate dietary changes over time in response to shifts in climate and food availability as well as dietary differences between individuals within the same social group (Oelze, 2016; Oelze et al., 2011, 2014, 2016a). Some aspects of diet may be reconstructed using stable isotopes because the ratios of the stable isotopes of carbon $\left({ }^{13} \mathrm{C} /{ }^{12} \mathrm{C}=\delta^{13} \mathrm{C}\right)$ and nitrogen $\left({ }^{15} \mathrm{~N} /{ }^{14} \mathrm{~N}=\delta^{15} \mathrm{~N}\right)$ in animal bodies are sourced from the predominant foods, which can vary drastically and thus be relevant dietary markers (DeNiro and Epstein, 1978, 1981). On the one hand, the $\delta^{13} \mathrm{C}$ values of plants differ substantially between $\mathrm{C}_{3}$ and $\mathrm{C}_{4}$ photosynthetic pathways (Tieszen, 1991), but also between high canopy and low canopy plant resources in forest habitats (Medina and Minchin, 1980; van der Merwe and Medina, 1989), and even between photosynthetic (e.g. foliage) and reproductive plant parts (e.g. fruits and flowers; Cernusak et al., 2009). In $\mathrm{C}_{3}$ plant dominated tropical rainforest habitats, we 
can expect the majority of variation in $\delta^{13} \mathrm{C}$ in herbivore consumers to be associated with differences in the consumption of high versus low canopy food items (e.g. arboreal fruit versus terrestrial herbs), as well as between reproductive and photosynthetic plant parts (e.g. fruit versus leaves; Blumenthal et al., 2016; Oelze et al., 2016a; Roberts et al., 2017).On the other hand, the $\delta^{15} \mathrm{~N}$ values in foods mainly relate to the trophic level of a food item, with plants revealing the lowest $\delta^{15} \mathrm{~N}$ values (DeNiro and Epstein, 1981). Primary consumers have significantly higher $\delta^{15} \mathrm{~N}$ values than the plants they eat, whereas carnivores reveal higher $\delta^{15} \mathrm{~N}$ values than herbivores (DeNiro and Epstein, 1981).

While differences between some food categories can be striking, there are several environmental factors that influence the isotopic variation within plants in a given habitat, including temperature (Barnes et al., 2007), rainfall (Nardoto et al., 2008; Sealy et al., 1987), altitude (Tieszen et al., 1979), soil composition (Dawson et al., 2002), as well as canopy density (Medina and Minchin, 1980). One strategy to cope with these environmental influences is to assess the local isotope baseline using a small yet representative plant sample, ideally consisting of plant foods frequently consumed by the study subjects (Oelze et al., 2011, 2016b). There is no widespread consensus on how extensive this plant sample should be to represent the habitat, and some studies still do not include any plant samples at all (Loudon et al., 2014; Schoeninger et al., 2015; Sponheimer et al., 2006). However, while these baseline values are crucial when comparing between primate groups ranging in different habitats with different environmental conditions (Oelze et al., 2016b), they may be less essential to studies focusing on intra-community differences as well as isotopic variation over time. 
156 Isotopic patterns can vary considerably between individuals and reveal information on 157 their access to food as well as on their physiological condition. For example, sex and/or social rank can result in a biased access to specific desirable foods which can be distinct in their $\delta^{15} \mathrm{~N}$ values, e.g. vertebrate meat (Fahy et al., 2013; Oelze et al., 2011, 2016a). Also the energetic demands of female reproduction (gestation, lactation) can affect her bodies nitrogen balance and thus skew the $\delta^{15} \mathrm{~N}$ values (Fuller et al., 2004; Oelze et al., 2016a). Further, there is good evidence that negative energy balance due to severe nutritional stress or fasting can result in shifts in nitrogen metabolism and thus $\delta^{15} \mathrm{~N}$ values in primates (Deschner et al., 2012; Mekota et al., 2006) and other animals (Hobson et al., 1993).

In this study, we evaluate to what extent stable isotope analysis can provide novel information regarding the feeding ecology of a natural population of mandrills living at the Lékédi Park and surroundings, in Southern Gabon. In particular, we focus on the effects of shifting environmental conditions (season) and individual characteristics (age, sex) on the $\delta^{13} \mathrm{C}$ and $\delta^{15} \mathrm{~N}$ values measured in mandrill body tissue samples. We here use two different sample tissues with two very different turnover rates and thus reflecting different periods in time. Blood isotope data is considered here to reflect the recent dietary contributions of the past day(s) with relatively high accuracy, whereas hair section isotope data relates to the isotopic characteristics of foods consumed over the previous months, with data representing weekly or monthly intervals. We assess to what extent these two different sample types pick up the same isotopic patterns.

Given the previous isotopic research in tropical forest of Gabon (Oelze et al., 2014), as well as previous observational data on this primate population (Nsi Akoue et al., 2017), we focus on the following predictions. Regarding the season of sampling, we expect 
180

isotopic values to vary between rainy and dry seasons, as fruit availability is commonly shifting with rainfall. Shifting proportions of foliage $v s$. fruit should particularly have an effect on the $\delta^{13} \mathrm{C}$ values of mandrills, with high fruit intake periods being associated with high $\delta^{13} \mathrm{C}$ values (Blumenthal et al., 2016; Cernusak et al., 2009; Oelze et al., 2016a; Roberts et al., 2017). Regarding individual age, we predict that the intense intrasexual competition observed in fully adult males (Setchell et al., 2005), as compared to younger, non-reproductive males, may result in nutritional stress particularly during the mating season (long dry season) with higher $\delta^{15} \mathrm{~N}$ values in mature males. Finally, regarding individual sex, we expect to find slightly higher $\delta^{15} \mathrm{~N}$ values in all females as compared to all males as females have been shown to consume more animal food items than males (Nsi Akoué et al., 2017), which can be expected to have higher $\delta^{15} \mathrm{~N}$ values than plant foods.

\section{Materials and Methods}

\section{Ethical statement}

This study complies with ethical protocols approved by the CENAREST institution (authorization number: AR003/20/MESRSTT/CENAREST/CG/CST/CSAR). This research adhered to the legal requirements of Gabon and to the American Society of Primatologists principles for the ethical treatment of nonhuman primates.

\section{Site and study population}

The study group originates from 65 captive individuals released into the park on two occasions in 2002 and 2006 (Peignot et al., 2008). Food supplementation with bananas and home-made cakes three to five times a week was initiated with the release, then 
gradually declined for a few years and totally ceased in April 2012 except during punctual trappings. The study population is monitored daily within the framework of a long-term field project (Mandrillus Project) started in early 2012. In 2018, the group was composed of ca. 180-200 habituated and individually identified mandrills, of which $\sim 90 \%$ were born in the wild. We collected tissue samples from a total of 43 individuals (24 males, 19 females) aged 2.2-19.3 yrs. Data on individual age in this study are based on observed birth dates $(n=12)$ or are based on general body conditions as well as tooth eruption and wear patterns (Galbany et al., 2014).

The study population ranges freely in the Lékédi Park and its surroundings near the village of Bakoumba. This private park covers an area of $116 \mathrm{~km}^{2}$ at an elevation varying from 430 to $610 \mathrm{~m}$. The habitat is composed of closed canopy forests and patches of savanna (Brockmeyer et al., 2015). Gabon is characterized by an equatorial climate with a long rainy season (Feb-May; in the studied site: monthly average temperature $=23.9^{\circ} \mathrm{C}$ and total rainfall $=240.5 \mathrm{~mm}$; data pooled from $04 / 2012-12 / 2014$ ), a long dry season (Jun-Sep; $22.1{ }^{\circ} \mathrm{C}$ and $18.9 \mathrm{~mm}$ ), a short rainy season (Oct-Nov; $23.3^{\circ} \mathrm{C}$ and $152.3 \mathrm{~mm}$ ) and a short dry season (Dec-Jan; $23.5^{\circ} \mathrm{C}$ and $133.3 \mathrm{~mm}$ ). These four climatic seasons have been shown to result in distinct diets in the studied mandrills, with no overlap in food selection between these seasons (see Figure 1 in: Nsi Akoué et al., 2017). In addition, reproduction is highly seasonal in mandrills, with most females cycling during the long dry season and giving birth during the short dry season or at the beginning of the long rainy season (MJEC, pers. obs). We therefore considered these four climatic seasons as a reliable indicator for the seasonality of mandrill behavior and ecology.

\section{Sample collection}


227 We collected hair tufts and blood samples from mandrills during four capture events between April 2012 and July 2014. During these events, mandrills were baited with food (mostly bananas) and anesthetized via blowpipe intramuscular injection of a ketamine-xylazine mix. After 30-40 min, individuals were awakened using atipamezole. During anesthesia, we plucked hair from the mandrills' arms or legs and stored them in paper envelopes that were then stored dry. We collected blood samples from the iliac vein of the individuals using heparinized tubes. Blood samples were centrifuged (15 min at $3000 \mathrm{rpm}$ ) the day of collection to obtain blood samples that were stored at $20^{\circ} \mathrm{C}$ (Beaulieu et al., 2017).

In 2014, we collected 24 food samples consumed by the studied mandrills, including 14 plant species, three mushroom and three insect species (Table S1). These items were selected randomly among the hundreds of food items known to be consumed by the studied population to gain a broad impression on the plant baseline values in the habitat, without an expectation of grasping the entire picture of plant isotope diversity. All selected plant species are frequently consumed by the studied mandrills $(>0.10$ occurrence per hour, as defined per: Nsi Akoué et al., 2017).

We prepared 214 hair sections from 62 hair samples. We selected 3 to 12 hairs of similar length, diameter and growth stage from each hair tuft and followed a sequential sectioning protocol (see for details: Oelze, 2016). Each hair sample provided up to 12 different sections of $1 \mathrm{~cm}$ ( 3.5 on average), which we sometimes combined to reach a weight suitable for a single isotopic measurement. We aliquoted $200 \mu \mathrm{L}$ of 46 blood samples and freeze-dried these samples for $24 \mathrm{~h}$ before analyses. Plants were dried the day of collection and homogenized thereafter. Insects and mushrooms were frozen at - 
$25020^{\circ} \mathrm{C}$ the day of collection, freeze-dried during $24 \mathrm{~h}$ and then homogenized using a 251 pebble mill before analyses.

252 Hair sections ( 0.33 to $0.74 \mathrm{mg})$, blood $(0.88$ to $1.14 \mathrm{mg})$ and food samples $(0.44$ to $2532.25 \mathrm{mg}$ ) were weighed into tin capsules for isotopic measurements performed parallel 254 to the IAEA standards CH6, CH7, N1 and N2 in a FLASH HT Plus coupled to a MAT 255253 IRMS (both by Thermo Scientific, Waltham, MA, USA) at the commercial 256 laboratory IsoDetect GmbH in Leipzig, Germany. Stable isotope ratios are expressed in 257 permil (\%o) using the delta $(\delta)$ notation and are calibrated against the international 258 standard materials Vienna PeeDee Belemite (vPDB) for carbon and atmospheric $\mathrm{N}_{2}$ 259 (AIR) for nitrogen. Analytical error calculated from repetitive measurements of 260 international and lab-internal standard materials in each run is less than $0.2 \%(2 \sigma)$ for $261 \delta^{15} \mathrm{~N}$ and $\delta^{13} \mathrm{C}$. Stable isotope ratios for hair sections, blood samples and food items are 262 hereafter referred to as $\delta^{13} \mathrm{C}_{\text {hair }}, \delta^{13} \mathrm{C}_{\text {blood }}$, and $\delta^{13} \mathrm{C}_{\text {diet }}$ as well as $\delta^{15} \mathrm{~N}_{\text {hair }}, \delta^{15} \mathrm{~N}_{\text {blood }}$, and $263 \delta^{15} \mathrm{~N}_{\text {diet. }}$. We removed one blood sample from the dataset because of its abnormally high 264 value of $\mathrm{C}: \mathrm{N}$ ratio (5.10 against an average value $=3.56 \pm 0.08)$.

\section{Estimation of diet-tissue fractionation factors}

266 Despite the small sample set we have for mandrill plant food items, we calculated 267 isotopic fractionation factors for both isotope systems $\left(\Delta^{15} \mathrm{~N}_{\text {hair-diet }}\right.$ and $\left.\Delta^{13} \mathrm{C}_{\text {hair-diet }}\right)$ 268 between broad categories of plant foods (reproductive parts $v s$. non-reproductive parts; 269 see: Table S1) and individual hair sections to obtain a broad impression of which plant 270 food category is relevant to mandrill diet and is reflected in hair isotope values. In 271 addition, this approach controls for baseline differences and allows to compare between 272 populations and sites with differing environmental conditions (Crowley et al., 2013; 273 Nakagawa et al., 2007; Oelze et al., 2016b). 
274

275

276

277

278

279

280

281

\section{Statistical analyses}

We conducted all statistical analyses in SAS Studio. To test for relationships between isotopic values obtained from hair and blood samples representing the same individual and the same time window, we used Pearson correlation tests. We used Linear Mixed Models (LMM, proc GLIMMIX) and Linear Models (LM, proc GLM) with Gaussian distributions to study the effects of seasonality and individual traits on both $\delta^{13} \mathrm{C}$ and $\delta^{15} \mathrm{~N}$ recorded in hair sections (LMM) and blood samples (LM). The normality of the models' residuals was systematically verified by visual inspection of the residuals' distribution in qq-plots and by conducting Kolmogorov-Smirnov tests. Note that in one model $\left(\delta^{15} \mathrm{~N}_{\text {hair }}\right)$, we removed six outlier samples to attain a Gaussian distribution of the data (leverage test, proc robustreg). We used differences in least square means as posthoc analyses for pairwise comparisons of categorical variables when appropriate. In all our statistical models performed, we considered all first order interactions and kept the full models as final models excluding only non-significant interactions $(\mathrm{p}>0.05)$.

We ran four independent models on the response valuables $\delta^{13} \mathrm{C}_{\text {hair }}, \delta^{15} \mathrm{~N}_{\text {hair }}, \delta^{13} \mathrm{C}_{\text {blood }}$ and $\delta^{15} \mathrm{~N}_{\text {blood }}$ to explore the effects of season, individual age and sex. We added the factor hair sample as a random effect in the two models on hair isotope values to control for pseudo-replication biases caused by multiple sampling of the hair tufts (Mundry and Oelze, 2015). We did not consider individual as a random effect in the analyses based on blood samples because only few animals out of our dataset were sampled more than once $(n=10)$.

We were unable to estimate mandrill hair growth rates, so we relied on human scalp hair growth rates as a rough estimate (see discussion in: Oelze, 2016). Hence, for each hair section analyzed, we calculated the corresponding time window based on a growth rate 
298 of $1 \mathrm{~cm}$ of hair per 30 days (Tobin, 2005), with the root date identical to the hair

299 collection date and the distal date corresponding to 30 days before.

300 In all four models we considered sex as a class variable and age as a continuous variable 301 (calculated at the distal date for hair and at the date of collection for blood). We 302 considered the effect of season as a class variable with two (blood) to three (hair) 303 modalities including a long rainy season, a long dry season, and the two short seasons 304 that we pooled together for the models based on hair because of limited sample sizes ( 7 305 samples only were collected during the small rainy season). In the models based on 306 blood, we considered the season at the exact date of sampling while in the models based 307 on hair, we considered the season at the distal date.

308 Food supplementation that occurred just before the beginning of sampling (early 2012) 309 may have impacted isotope values in the distal sections of long mandrills' hair (the ones 310 spanning the supplementation period that ceased in April 2012). Although preliminary analyses by removing these potentially biased hair sections. We found similar results to those obtained from full datasets and therefore chose to include these 314 samples in the final models.

317 We obtained a total of 46 isotopic measurements for blood and 214 measurements in 318 hair sections. The $\delta^{13} C_{\text {hair }}$ values range from $-26.1 \%$ o to $-24.0 \%$ (mean $\pm 1 \sigma:-25.1 \pm$ $3190.3 \%$ ), slightly higher than $\delta^{13} C_{\text {blood }}$ values which vary between $-27.7 \%$ and $-25.8 \%$ o ($32026.6 \pm 0.4 \%$ ). The $\delta^{15} \mathrm{~N}_{\text {hair }}$ values range from $4.21 \%$ o to $7.8 \%$ o $(6.0 \pm 0.5 \%$ ) while 
$321 \delta^{15} \mathrm{~N}_{\text {blood }}$ values vary less and range between 5.6\%o and 7.5\%o (6.4 $\pm 0.3 \%$ ). Isotopic measurements retrieved from hair sections and blood samples collected from the same individual on the same day $(\mathrm{n}=37)$ are significantly correlated (Figure $\mathrm{S} 1)$. Despite the small plant food dataset from the studied habitat, we can report that non-reproductive plant parts $\left(-32.2 \pm 3.0 \%\right.$ ) yielded on average $\sim 2 \%$ lower $\delta^{13} \mathrm{C}$ values than reproductive plant parts $\left(-30.3 \pm 2.6 \%\right.$ ). In addition, $\delta^{15} \mathrm{~N}$ values were on average higher in nonreproductive plant parts $(6.0 \pm 3.8 \%)$ than in reproductive plant parts $(3.7 \pm 1.1 \%)$. The few arthropods we analyzed (ants, butterfly, caterpillar) did not have higher $\delta^{15} \mathrm{~N}$ values than plant foods (Table S1). Mean fractionation factors between mandrill hair and reproductive plant parts, comprised by fruits, seeds and some flowers, resulted in mean $\Delta{ }^{15} \mathrm{~N}_{\text {hair-fruit }}$ values of $2.3 \%$ and mean $\Delta{ }^{13} \mathrm{C}_{\text {hair-fruit values of } 5.2 \% \text {. The calculated mean }}$ fractionation values between mandrill hair and non-reproductive plant parts (leaves) were $0.0 \%$ for $\Delta^{15} \mathrm{~N}_{\text {hair-leaves }}$ and $7.1 \%$ for $\Delta^{13} \mathrm{C}_{\text {hair-leaves. }}$

\section{Effect of season}

In the $\delta^{13} \mathrm{C}_{\text {blood }}$ model, isotopic values were significantly higher during the rainy season (see Table 1 for detailed statistical results; Figure 1A). In the $\delta^{13} \mathrm{C}_{\text {hair }}$ model, however, the factor season was interacting with the predictors sex and age (Table 1). In females, the lowest $\delta^{13} \mathrm{C}$ values of hair were found during the long rainy season, while we observed exactly the reverse in males (Figure 2). Although the interaction between age and season was not obvious, younger animals, especially males, tended to show higher $\delta^{13} \mathrm{C}$ values of hair (Figure 2). The $\delta^{15} \mathrm{~N}$ values of blood were significantly higher during the long dry season compared to the long rainy season (Table 1; Figure 1B). By contrast, the effect of seasonality was not captured by the $\delta^{15} \mathrm{~N}$ values of hair (Table 1 ). 
346

347

Effects of individual age and sex

Individual age had a significant effect on $\delta^{13} \mathrm{C}$ values of blood which decreased with mandrill's age in male subjects (Table 1; Figure 3). Finally, we found significant interactions between individual age and sex on $\delta^{15} \mathrm{~N}$ values of blood and hair: older males showed higher values than younger males and this age effect was not observed in females (Table 1; Figure 4A and B).

\section{Discussion}

We here report the first isotopic study conducted on free ranging mandrills in which we investigated effects of season and individual traits such as age and sex on feeding behavior. The limited plant isotope data set allowed a glimpse into the natural isotopic variation of food items in the mandrill habitat to understand how to interpret findings of lower or higher isotope values across seasons and individuals. Similar to isotopic values reported in several forests of Central and West African countries (Oelze et al., 2014; Oelze et al., 2016b), the low $\delta^{13} \mathrm{C}$ values of the 14 plant species collected in the Lékédi Park (mean: $-31.3 \%$ ) indicate that mandrills' habitat is similarly depleted in ${ }^{13} \mathrm{C}$ as other forest habitats in Gabon, such as Loango with a mean plant $\delta^{13} \mathrm{C}$ value of $-30.5 \%$ o (Oelze et al., 2014), although additional plant isotope data would be desirable to confirm this finding.

The $\delta^{13} \mathrm{C}$ values of mandrills' hair sections $(-25.1 \pm 0.3 \%$ ) are within the range of those obtained from hair of sympatric great apes also living in Gabon, namely central chimpanzees (from $-25.7 \%$ to $-23.4 \%$ ) and lowland gorillas (from $-27.1 \%$ o to $-24.5 \%$ ) 
from Loango National Park (Oelze et al., 2014). Similar to these species, mandrills live in dense rainforest habitats strongly affected by the so called canopy effect (van der Merwe and Medina, 1989). As expected, mandrills yielded much lower $\delta^{13} \mathrm{C}$ values than those found in South African chacma baboons (ranging from -19.8\%o to $-18.5 \%$ ) as these baboons live in an open semiarid environment and $\sim 20-30 \%$ of their diet is comprised by $\mathrm{C}_{4}$ plants (Codron et al., 2006). Mandrills showed on average higher $\delta^{15} \mathrm{~N}_{\text {hair }}$ values $(6.0 \pm 0.4 \%$ ) than chimpanzees and gorillas from Gabon (5.0\%o and 4.2\%o, resp.), which is well explained by the slightly lower mean $\delta^{15} \mathrm{~N}$ value in plants from Loango (4.2 at Lékédi vs. 3.3\% at Loango; Oelze et al., 2014). These similarities with other species in both isotope systems would suggest that the dietary pattern observed in mandrills is comparable to the dietary niche of terrestrial great apes in other parts of Gabon, particularly to the higher level of frugivory as seen in chimpanzees. While our food item isotope dataset was too small to conduct dietary mixing models, at least the fractionation factors we calculated between different plant categories and mandrills seem to support this finding, as the relationship between mandrill hair and the different plant foods found a better match between reproductive plant parts (fruits, seeds and flowers) than it did with foliage. $\Delta^{13} \mathrm{C}_{\text {hair-fruit }}$ values between $\sim 3$ and $5 \%$ and $\Delta{ }^{15} \mathrm{~N}_{\text {hair-fruit }}$ values between $\sim 2$ and $4 \%$ are reported for several populations of frugivorous great apes in different regions of Africa (Oelze et al., 2016b). This very general observation is well in line with direct observations of mandrill foraging behavior which suggests that their diet consists of 70 to $90 \%$ of fruit (Nsi Akoue et al., 2017). For non-reproductive plant parts (foliage) the fractionation values were either too low $\left(0.0 \% \Delta^{15} \mathrm{~N}_{\text {hair-leaves }}\right)$ or too high $\left(7.1 \% \Delta^{13} \mathrm{C}_{\text {hair-leaves }}\right)$ to be considered reflecting foliage as a substantial dietary contribution. However, this mismatch could also be related to a data bias introduced by 
using a very small and possibly not representative sample of leaves, that likely does not encompass the full isotopic variation within non-reproductive plant parts in the mandrills' diet. Particularly leaves can vary substantially in their $\delta^{13} \mathrm{C}$ values depending on whether they are sampled on the forest floor, understory or high up in the canopy (Medina and Minchin, 1980; van der Merwe and Medina, 1991; Carlson and Kingston, 2014; Oelze et al., 2014, 2016a; Carlson and Crowley, 2016; Roberts et al., 2017), which may make comparisons of hair-leave values less reliable than calculation referring to reproductive plant parts alone (Oelze et al., 2016b).

We found some isotopic differences across seasons. We expected to find isotopic variation in response to shifts in fruit availability between the dry and rainy seasons. In Gabon, the rainy season generally corresponds to higher fruit availability (White, 1994; but see: Head et al., 2011) and high fruit intake periods should be associated with higher $\delta^{13} \mathrm{C}$ values (Cernusak et al., 2009; Oelze et al., 2014, 2016b). As such, we found higher $\delta^{13} \mathrm{C}$ values of blood across all studied mandrills and also higher $\delta^{13} \mathrm{C}$ values of hair in males during the long rainy season compared to the long dry season. It remains unclear if this seasonal pattern in $\delta^{13} \mathrm{C}$ values could be related to general seasonal changes within the $\delta^{13} \mathrm{C}$ values of plant food categories. Previous research on primate forest plant foods did not suggest that seasonal variation is considerable (Carlson and Kingston, 2014) and we thus did not systematically collect samples from the same food plants across different seasons in this study.,

The $\delta^{13} \mathrm{C}$ values of hair in females did not follow this seasonal pattern in $\delta^{13} \mathrm{C}$ value, possibly reflecting some sex-related differences in physiology or seasonal feeding preferences. During the long dry season, most females are, indeed, cycling or are in early pregnancy (see Figure 1 in: Dibakou et al., 2019), and the specific nutritional 
416 demands of maternal investment have been shown to affect the feeding behavior and $417 \quad \delta^{13} \mathrm{C}$ values of other large bodied primates (Oelze et al. 2016). The long dry season also

418

419

420

421

422 caused higher $\delta^{15} \mathrm{~N}$ values in blood of the studied mandrills, although this season does not correspond to the highest animal's consumption in the studied population (Nsi Akoué et al., 2017). This apparent contradictory finding probably results from highly shifted $\delta^{15} \mathrm{~N}$ values in adult male mandrills (see below).

Variation in $\delta^{13} \mathrm{C}$ values of blood was mainly predicted by age but not sex, whereas $\delta^{15} \mathrm{~N}$ variation was driven by the interaction between individual age and sex. In blood and, to a lesser extent, in male hair section samples, the $\delta^{13} \mathrm{C}$ values were significantly higher in young individuals compared to old mandrills. Given that variation in plant $\delta^{13} \mathrm{C}$ values is primarily driven by canopy height (lower values in understory than in canopy) and plant part (lower values in foliage than in fruit) in rainforest communities, we can interpret higher $\delta^{13} \mathrm{C}$ values in young mandrills to be the result of consuming significantly less low canopy plant foods and/or foliage, but more fruit from higher in the canopy. Significant diet differences across age classes have been observed during the long dry season in the studied mandrills. At this time of the year, interestingly, the highest frequencies of fruit consumption was observed in juvenile males and adolescent females (see Supplementary Information in: Nsi Akoué et al., 2017). Although, we cannot comment further on this possible relationship, it seems puzzling as one may predict that older, more experienced mandrills should be able to find ripe fruit better than younger individuals. Alternatively, instead of high canopy fruit, the infrequent consumption of $\mathrm{C}_{4}$ grasses may explain the higher $\delta^{13} \mathrm{C}$ values in young individuals. However, we have little to no evidence that $\mathrm{C}_{4}$ grasses possibly available in the open savanna patches are of any relevance to the mandrills feeding ecology. Finally, young 
440 mandrills were found, among others, to consume significantly more Ficus mucuso but 441 less Aframomum alboviolaceum than adults in the study population (Nsi Akoué et al., 2017). While fruits of the former should result in high $\delta^{13} \mathrm{C}$ values, because they are generally found high in the canopy, the latter should result in low $\delta^{13} \mathrm{C}$ values because it is a terrestrial herbaceous species. These observations are consistent with our current findings.

We anticipated to additionally find another effect of age on the dietary behavior of mandrills as particularly older and reproductively active males may undergo periods of nutritional stress during and around the mating season. An endocrinological study on this mandrill population suggested high fecal glucocorticoid values in old males during the mating season (long dry season) due to the influx of new competing males and intense and aggressive male-male competition in this species (Charpentier et al., 2018). This may suggest that older males undergo negative energy balance for several months a year. Our models and the $\delta^{15} \mathrm{~N}$ values obtained from both blood and hair sections appear to support this assumption, with increasing $\delta^{15} \mathrm{~N}$ values with age in males. We assume that higher $\delta^{15} \mathrm{~N}$ values in older males result from nutritional stress in response to the intense male-male competition during the mating season. Mature male mandrills fiercely fight over access to female and dedicate less time to feeding, resulting in higher stress levels and negative energy balance (Charpentier et al., 2018). Adult males indeed spend less time foraging compared to all other individuals (Nsi Akoué et al., 2017). The $\delta^{15} \mathrm{~N}$ values are known to increase in response to severe negative energy balance. When basic metabolic requirements in nitrogen (protein) are not met through diet, it has to be acquired from body own proteins through catabolism. Higher mobilization and excretion of body own nitrogen then contributes to a reduction in body mass (Deschner 
et al., 2012). The reduction of net energy intake has to be substantial in order to lead to reduction in body mass, and the condition has to be experienced for a prolonged period of time in order to affect the animals physiology, nitrogen balance and in consequence the bodies $\delta^{15} \mathrm{~N}$ values (Barboza and Parker, 2006; Hobson et al., 1993). Changes in $\delta^{15} \mathrm{~N}$ values due to nutritional stress have rarely been shown in non-human and human primates (Deschner et al., 2012; D’Ortenzio et al., 2015; Mekota et al., 2006, 2009). This is the first study reporting isotopic evidence for nutritional stress in a free-ranging primate supported by observational data, suggesting that nutritional stress experienced by reproductive male mandrills is traceable using isotope analysis and worth future more detailed investigation.

Finally, we anticipated to find slightly higher $\delta^{15} \mathrm{~N}$ values in all females as compared to all males. As the first direct observations of this population of mandrills suggested that females consumed more animal food items than males (Nsi Akoue et al., 2017). However, we found no support for this third prediction. We did not find higher $\delta^{15} \mathrm{~N}$ values in the three arthropods collected at the Lékédi Park than what we found in a variety of plant foods (Table S1). Further, females did not show higher average $\delta^{15} \mathrm{~N}$ values than males across age classes. In fact, we found the opposite: females generally showed slightly lower $\delta^{15} \mathrm{~N}$ values than males, which we think is mainly driven by the higher $\delta^{15} \mathrm{~N}$ levels in productively active and thus nutritionally stressed male mandrills.

This is the first isotopic investigation conducted in a large population of free-ranging mandrills. Our results partly confirm observational data, but also highlighted some potential future avenues for behavioral research, particularly regarding dietary differences between age classes as well as nutritional stress in reproductively active males. 


\section{Acknowledgements}

489 We thank past and present field assistants of the Mandrillus Project for their help in data 490 collection. We are grateful to Ilham Bentaleb for useful discussions regarding stable 491 isotopes. Alice Baniel also helped with data analyses. Laboratory analyses were 492 performed at the Plateforme d'Analyses Chimiques en Ecologie (PACE; Montpellier, 493 France), the Max Planck Institute for Evolutionary Anthropology (Leipzig, Germany) 494 and in the commercial laboratory IsoDetect GmbH (Leipzig, Germany). This study was 495 funded by a grant from the Deutsche Forschungsgemeinschaft grant (DFG, KA-1082496 20-1), and from INEE-CNRS ("Station d'Etudes en Ecologie Globale" and a 497 "Laboratoire International Associé") to MJEC. This is a Mandrillus Project publication 498 number 23 and a ISEM 2020-171 SUD. 
500

501

502

503

504

505

506

507

508

509

510

511

512

513

514

515

516

517

518

519

520

\section{References}

Abernethy, K.A., White, L.J.T., and Wickings, E.J. (2002). Hordes of mandrills (Mandrillus sphinx): Extreme group size and seasonal male presence. Journal of Zoology, 258, 131-137.

Barboza, P.S., \& Parker, K.L. (2006). Body protein stores and isotopic indicators of N balance in female reindeer (Rangifer tarandus) during winter. Physiological and Biochemical Zoology, 79, 628-644.

Barnes, C., Sweeting, C.J., Jennings, S., Barry, J.T., \& Polunin, N.V.C. (2007). Effect of temperature and ration size on carbon and nitrogen stable isotope trophic fractionation. Functional Ecology, 21, 356-362.

Beaulieu, M., Benoit, L., Abaga, S., Kappeler, P.M., \& Charpentier, M.J.E. (2017). Mind the cell: Seasonal variation in telomere length mirrors changes in leucocyte profile. Molecular Ecology, 26, 5603-5613.

Blumenthal, S.A., Rothman, J.M., Chritz, K.L., \& Cerling, T.E. (2016). Stable isotopic variation in tropical forest plants for applications in primatology. American Journal of Primatology, 78, 1041-1054.

Brockmeyer, T., Kappeler, P.M., Willaume, E., Benoit, L., Mboumba, S., \& Charpentier, M.J.E. (2015). Social organization and space use of a wild mandrill (Mandrillus sphinx) group. American Journal of Primatology, 77, 1036-1048.

Carlson, B.A., \& Crowley, B.E. (2016). Variation in carbon isotope values among chimpanzee foods at Ngogo, Kibale National Park and Bwindi Impenetrable National Park, Uganda. American Journal of Primatology, 78, 1031-1040.

Carlson, B.A., \& Kingston, J.D. (2014). Chimpanzee isotopic ecology: A closed canopy C3 template for hominin dietary reconstruction. Journal of Human Evolution, 76, 107115.

Cernusak, L.A., Tcherkez, G., Keitel, C., Cornwell, W.K., Santiago, L.S., Knohl, A., ... Wright, I.J. (2009). Why are non-photosynthetic tissues generally $13 \mathrm{C}$ enriched compared with leaves in C3 plants? Review and synthesis of current hypotheses. Functional Plant Biology, 36, 199-213.

Clutton-Brock, T., \& Janson, C. (2012). Primate socioecology at the crossroads: Past, present, and future. Evolutionary Anthropology Issues News and Reviews, 21, 136-150.

Codron, D., Lee-Thorp, J.A., Sponheimer, M., de Ruiter, D., \& Codron, J. (2006). Interand intrahabitat dietary variability of chacma baboons (Papio ursinus) in South African savannas based on fecal $\delta 13 \mathrm{C}, \delta 15 \mathrm{~N}, \& \% \mathrm{~N}$. American Journal of Physical Anthropology, 129, 204-214. 
Codron, D., Lee-Thorp, J.A., Sponheimer, M., de Ruiter, D., \& Codron, J. (2008). What insights can baboon feeding ecology provide for early hominin niche differentiation? International Journal of Primatology, 29, 757-772.

Crowley, B.E. (2012). Stable isotope techniques and applications for primatologists. International Journal of Primatology, 33, 673-701.

Crowley, B.E., Blanco, M.B., Arrigo-Nelson, S.J., \& Irwin, M.T. (2013). Stable isotopes document resource partitioning and effects of forest disturbance on sympatric cheirogaleid lemurs. Naturwissenschaften, 100, 943-956.

Crowley, B.E., Reitsema, L.J., Oelze, V.M., \& Sponheimer, M. (2015). Advances in primate stable isotope ecology-Achievements and future prospects. American Journal of Primatology, 78, 995-1003.

Dawson, T.E., Mambelli, S., Plamboeck, A.H., Templer, P.H., \& Tu, K.P. (2002). Stable isotopes in plant ecology. Annual Review of Ecology, Evolution, and Systematics, $33,507-559$.

DeNiro, M.J., \& Epstein, S. (1978). Influence of diet on the distribution of carbon isotopes in animals. Geochimica and Cosmochimica Acta, 42, 495-506.

DeNiro, M.J., \& Epstein, S. (1981). Influence of diet on the distribution of nitrogen isotopes in animals. Geochimica and Cosmochimica Acta, 45, 341-351.

Deschner, T., Fuller, B.T., Oelze, V.M., Boesch, C., Hublin, J.-J., Mundry, R., ... Hohmann, G. (2012). Identification of energy consumption and nutritional stress by isotopic and elemental analysis of urine in bonobos (Pan paniscus). Rapid Communication in Mass Spectrometry, 26, 69-77.

D’Ortenzio, L., Brickley, M., Schwarcz, H., \& Prowse, T. (2015). You are not what you eat during physiological stress: Isotopic evaluation of human hair. American Journal of Physical Anthropology, 157, 374-388.

Fahy, G.E., Richards, M., Riedel, J., Hublin, J.-J., \& Boesch, C. (2013). Stable isotope evidence of meat eating and hunting specialization in adult male chimpanzees. Proceedings of the National Academy of Sciences, 110, 5829-5833.

Fourie, N.H., Brown, J.L., Jolly, C.J., Phillips-Conroy, J.E., Rogers, J., \& Bernstein, R.M. (2016). Sources of variation in hair cortisol in wild and captive non-human primates. Zoology, 119, 119-125.

Fuller, B.T., Fuller, J.L., Sage, N.E., Harris, D.A., O'Connell, T.C., \& Hedges, R.E.M. (2004). Nitrogen balance and $15 \mathrm{~N}$ : Why you're not what you eat during pregnancy. Rapid Communication in Mass Spectrometry, 18, 2889-2896.

Galbany, J., Romero, A., Mayo-Alesón, M., Itsoma, F., Gamarra, B., Pérez-Pérez, A., ... Charpentier, M.J.E. (2014). Age-related tooth wear differs between forest and savanna primates. PLoS ONE, 9(4), e94938. 
Harrison, M.J.S. (1988). The mandrill in Gabon's rain forest - Ecology, distribution and status. Oryx, 22, 218-228.

Head, J.S., Boesch, C., Makaga, L., \& Robbins, M.M. (2011). Sympatric chimpanzees (Pan troglodytes troglodytes) and gorillas (Gorilla gorilla gorilla) in Loango National Park, Gabon: Dietary composition, seasonality, \& intersite comparisons. International Journal of Primatology, 32, 755-775.

Hobson, K.A., \& Clark, R.G. (1992). Assessing avian diets using stable isotopes .1. Turnover of C-13 in Tissues. Condor, 94, 181-188.

Hobson, K.A., Alisauskas, R.T., \& Clark, R.G. (1993). Stable nitrogen isotope enrichment in avian tissues due to fasting and nutritional stress - Implications for isotopic analyses of diet. Condor, 95, 388-394.

Hoshino, J., Mori, A., Kudo, H., \& Kawai, M. (1984). Preliminary report on the grouping of mandrills (Mandrillus sphinx) in Cameroon. Primates, 25, 295-307.

Lahm, S.A. (1986). Diet and habitat preference of Mandrillus sphinx in Gabon: Implications of foraging strategy. American Journal of Primatology, 11, 9-26.

Lambert, J.E., \& Rothman, J.M. (2015). Fallback foods, optimal diets, \& nutritional targets: Primate responses to varying food availability and quality. Annual Review of Anthropology, 44, 493-512.

Loudon, J.E., Grobler, P., Sponheimer, M., Moyer, K., Lorenz, J.G., \& Turner, T.R. (2014). Using the stable carbon and nitrogen isotope compositions of vervet monkeys (Chlorocebus pygerythrus) to examine questions in ethnoprimatology. PLoS One, 9, e100758.

McGraw, W.S., \& Daegling, D.J. (2012). Primate feeding and foraging: Integrating studies of behavior and morphology. Annual Review of Anthropology, 41, 203-219.

Medina, E., \& Minchin, P. (1980). Stratification of d ${ }^{13}$ C values of leaves in Amazonian rain forests. Oecologia, 45, 377-378.

Mekota, A.M., Grupe, G., Ufer, S., \& Cuntz, U. (2006). Serial analysis of stable nitrogen and carbon isotopes in hair: Monitoring starvation and recovery phases of patients suffering from anorexia nervosa. Rapid Communication in Mass Spectrometry, $20,1604-1610$.

Mekota, A.M., Grupe, G., Ufer, S., \& Cuntz, U. (2009). Identifying starvation episodes using stable isotopes in hair Forensic approach on serial hair analysis. Rechtsmedizin, $19,431-438$.

van der Merwe, N.J., \& Medina, E. (1989). Photosynthesis and ${ }^{13} \mathrm{C}^{12} \mathrm{C}$ ratios in Amazonian rain forests. Geochimica and Cosmochimica Acta, 53, 1091-1094.

van der Merwe, N.J., \& Medina, E. (1991). The canopy effect, carbon isotope ratios and foodwebs in Amazonia. Journal of Archaeological Science, 18, 249-259. 
Mundry, R., \& Oelze, V.M. (2015). Who is who matters - The effects of pseudoreplication in stable isotope analyses. American Journal of Primatology, 78, 1017-1030.

Nakagawa, M., Hyodo, F., \& Nakashizuka, T. (2007). Effect of forest use on trophic levels of small mammals: An analysis using stable isotopes. Canadian Journal of Zoology, 85, 472-478.

Nardoto, G.B., Ometto, J.P.H.B., Ehleringer, J.R., Higuchi, N., Bustamante, M.M.D.C., \& Martinelli, L.A. (2008). Understanding the influences of spatial patterns on $\mathrm{N}$ availability within the Brazilian Amazon forest. Ecosystems, 11, 1234-1246.

Nsi Akoue, G., Mbading-Mbading, W., Willaume, E., Souza, A., Mbatchi, B., \& Charpentier, M.J.E. (2017). Seasonal and individual predictors of diet in a free-ranging population of mandrills. Ethology, 123, 600-613.

O'Connell, T.C., \& Hedges, R.E. (1999). Investigations into the effect of diet on modern human hair isotopic values. American Journal of Physical Anthropology, 108, 409-425.

Oelze, V.M. (2016). Reconstructing temporal variation in great ape and other primate diets: A methodological framework for isotope analyses in hair. American Journal of Primatology, 78, 1004-1016.

Oelze, V.M., Fuller, B.T., Richards, M.P., Fruth, B., Surbeck, M., Hublin, J.-J., \& Hohmann, G. (2011). Exploring the contribution and significance of animal protein in the diet of bonobos by stable isotope ratio analysis of hair. Proceedings of the National Academy of Sciences, 108, 9792-9797.

Oelze, V.M., Head, J.S., Robbins, M.M., Richards, M., \& Boesch, C. (2014). Niche differentiation and dietary seasonality among sympatric gorillas and chimpanzees in Loango National Park (Gabon) revealed by stable isotope analysis. Journal of Human Evolution, 66, 95-106.

Oelze, V.M., Douglas, P.H., Stephens, C.R., Surbeck, M., Behringer, V., Richards, M.P., ... Hohmann, G. (2016a). The steady state great ape? Long term isotopic records reveal the effects of season, social rank and reproductive status on bonobo feeding behavior. PLoS ONE, 11, 1-17.

Oelze, V.M., Fahy, G., Hohmann, G., Robbins, M.M., Leinert, V., Lee, K., ... Kühl, H.S. (2016b). Comparative isotope ecology of African great apes. Journal of Human Evolution, 101, 1-16.

Peignot, P., Charpentier, M.J.E., Bout, N., Bourry, O., Massima, U., Dosimont, O., ... Wickings, E.J. (2008). Learning from the first release project of captive-bred mandrills Mandrillus sphinx in Gabon. Oryx, 42, 122-131.

Roberts, P., Blumenthal, S.A., Dittus, W., Wedage, O., \& Lee-Thorp, J.A. (2017). Stable carbon, oxygen, and nitrogen, isotope analysis of plants from a South Asian 
647

648

649

650

651

652

653

654

655

656

tropical forest: Implications for primatology. American Journal of Primatology, 79, e22656.

Rogers, M.E., Abernethy, K.A., Fontaine, B., Wickings, E.J., White, L.J.T., \& Tutin, C.E.G. (1996). Ten days in the life of a mandrill horde in the Lopé Reserve, Gabon. American Journal of Primatology, 40, 297-313.

Sandberg, P.A., Loudon, J.E., \& Sponheimer, M. (2012). Stable Isotope Analysis in Primatology: A Critical Review. American Journal of Primatology, 74, 969-989.

van Schaik, C.P. (1989). The ecology of social relationships amongst female primates. In V. Standen \& Foley R.A. (Eds.), Comparative socioecology: The behavioural ecology of humans and other mammals (pp. 195-218). Oxford, UK: Blackwell.

Schoeninger, M.J., Most, C.A., Moore, J.J., \& Somerville, A.D. (2015). Environmental variables across Pan troglodytes study sites correspond with the carbon, but not the nitrogen, stable isotope ratios of chimpanzee hair. American Journal of Primatology, $78,1055-1069$.

Schwertl, M., Auerswald, K., \& Schnyder, H. (2003). Reconstruction of the isotopic history of animal diets by hair segmental analysis. Rapid Communication in Mass Spectrometry, 17, 1312-1318.

Sealy, J.C., van der Merwe, N.J., Thorp, J.A.L., \& Lanham, J.L. (1987). Nitrogen isotopic ecology in southern Africa: Implications for environmental and dietary tracing. Geochimica and Cosmochimica Acta, 51, 2707-2717.

Sponheimer, M., Loudon, J.E., Codron, D., Howells, M.E., Pruetz, J.D., Codron, J., ... Lee-Thorp, J.A. (2006). Do "savanna" chimpanzees consume C-4 resources? Journal of Human Evolution, 51, 128-133.

Sterck, E.H., Watts, D.P., \& Van Schaik, C.P. (1997). The evolution of female social relationships in nonhuman primates. Behavioral Ecology and Sociobiology, 41, 291309.

Tieszen, L.L. (1991). Natural variations in the carbon isotope values of plants: implications for archaeology, ecology and paleoecology. Journal of Archaeological Science, 18, 227-248.

Tieszen, L.L., Senyimba, M.M., Imbamba, S.K., \& Troughton, J.H. (1979). The distribution of $\mathrm{C} 3$ and $\mathrm{C} 4$ grasses and carbon isotope discrimination along an altitudinal and moisture gradient in Kenya. Oecologia, 37, 337-350.

Tobin, D.J. (2005). The biogenesis and growth of hair. In D.J. Tobin (Ed.), Hair in Toxycology. An Important Bio-Monitor (pp. 3-33). Cambridge, UK: The Royal Society of Chemistry.

Tutin, C.E.G., \& Fernandez, M. (1993). Composition of the diet of chimpanzees and comparisons with that of sympatric lowland gorillas in the Lopé reserve, Gabon. American Journal of Primatology, 30, 195-211. 
685 White, C.D., \& Schwarcz, H.P. (1994). Temporal trends in stable isotopes for Nubian 686 mummy tissues. American Journal of Physical Anthropology, 93, 165-187.

687 White, L.J.T. (1994). Patterns of fruit-fall phenology in the Lopé Reserve, Gabon. 688 Journal of Tropical Ecology, 10, 313-322. 
689 Table 1: Results of the four Mixed Models on the responses of $\delta^{15} \mathrm{~N}$ and $\delta^{13} \mathrm{C}$ in hair 690 sections and blood samples, with the fixed effects of the season, individual age and sex.

\begin{tabular}{|c|c|c|c|c|}
\hline Response & Sample sizes & Fixed effects & Statistics & p-value \\
\hline \multirow[t]{5}{*}{$\delta^{13} C_{\text {hair }}$} & 214 hair sections & Season & $\mathrm{F}=3.82$ & 0.024 \\
\hline & 62 hair samples & Age & $F=13.22$ & $<0.001$ \\
\hline & 37 individuals & Sex & $\mathrm{F}=5.00$ & 0.027 \\
\hline & & Sex*Season & $\mathrm{F}=3.33$ & 0.039 \\
\hline & & Age*Season & $\mathrm{F}=3.06$ & 0.050 \\
\hline \multirow[t]{3}{*}{$\delta^{13} C_{\text {blood }}$} & 46 blood samples & Season & $\mathrm{F}=21.52$ & $<0.001$ \\
\hline & 36 individuals & Age & $\mathrm{F}=8.09$ & 0.007 \\
\hline & & Sex & $\mathrm{F}=0.73$ & 0.400 \\
\hline \multirow[t]{4}{*}{$\delta^{15} N_{\text {hair }}$} & 208 hair sections & Season & $\mathrm{F}=0.93$ & 0.400 \\
\hline & 61 hair samples & Age & $\mathrm{F}=2.23$ & 0.140 \\
\hline & 37 individuals & Sex & $\mathrm{F}=4.34$ & 0.004 \\
\hline & & Sex*Age & $\mathrm{F}=6.51$ & 0.012 \\
\hline \multirow[t]{4}{*}{$\delta^{15} N_{\text {blood }}$} & 46 blood samples & Season & $\mathrm{F}=33.55$ & $<0.001$ \\
\hline & 36 individuals & Age & $\mathrm{F}=7$ & $<0.001$ \\
\hline & & Sex & $\mathrm{F}=8.46$ & 0.006 \\
\hline & & Sex*Age & $\mathrm{F}=24.58$ & $<0.001$ \\
\hline
\end{tabular}

691 
692 Figure captions

693

694 Figure 1: Whisker boxplots with median, upper/lower quartiles and $\mathrm{min} / \mathrm{max}$ ranges

695 illustrating the effect of seasonal differences in mandrill isotope values between the long 696 dry and the long rainy seasons revealed by the $\delta^{13} \mathrm{C}(\mathrm{A})$ and $\delta^{15} \mathrm{~N}(\mathrm{~B})$ values of mandrill 697 blood.

698

699 Figure 2: Whisker boxplots with median, upper/lower quartiles and $\mathrm{min} / \mathrm{max}$ ranges 700 illustrating the effect of seasonal differences in mandrill $\delta^{13} \mathrm{C}$ values of hair by sex (A: 701 males, B: females) and age class (young $<10$ years, old $>10$ years). Two age classes 702 were defined here for the sake of clarity, although age was considered as a continuous 703 predictor in our statistical models.

Figure 3: Scatter plot showing the relationship between individual age and $\delta^{13} \mathrm{C}$ values of blood.

Figure 4: Scatter plots showing the relationships between individual age in years and $\delta^{15} \mathrm{~N}$ values in mandrill hair (grey symbols) and blood (black symbols) separate for males (A) and females (B). 


\section{Research Highlights}

- Stable isotope analyses of hair and blood have the potential to provide short and longterm data on how individual diets may shift over the season and with individual traits.

- Dietary patterns differ across seasons, between sexes as well as between young and older mandrills.

- Mature and reproductively active male mandrills showed the highest nitrogen isotope values as a result of nutritional stress possibly associated to intense male-male competition in this species.

- This is the first study showing isotopic evidence for nutritional stress in a free-ranging primate species. 


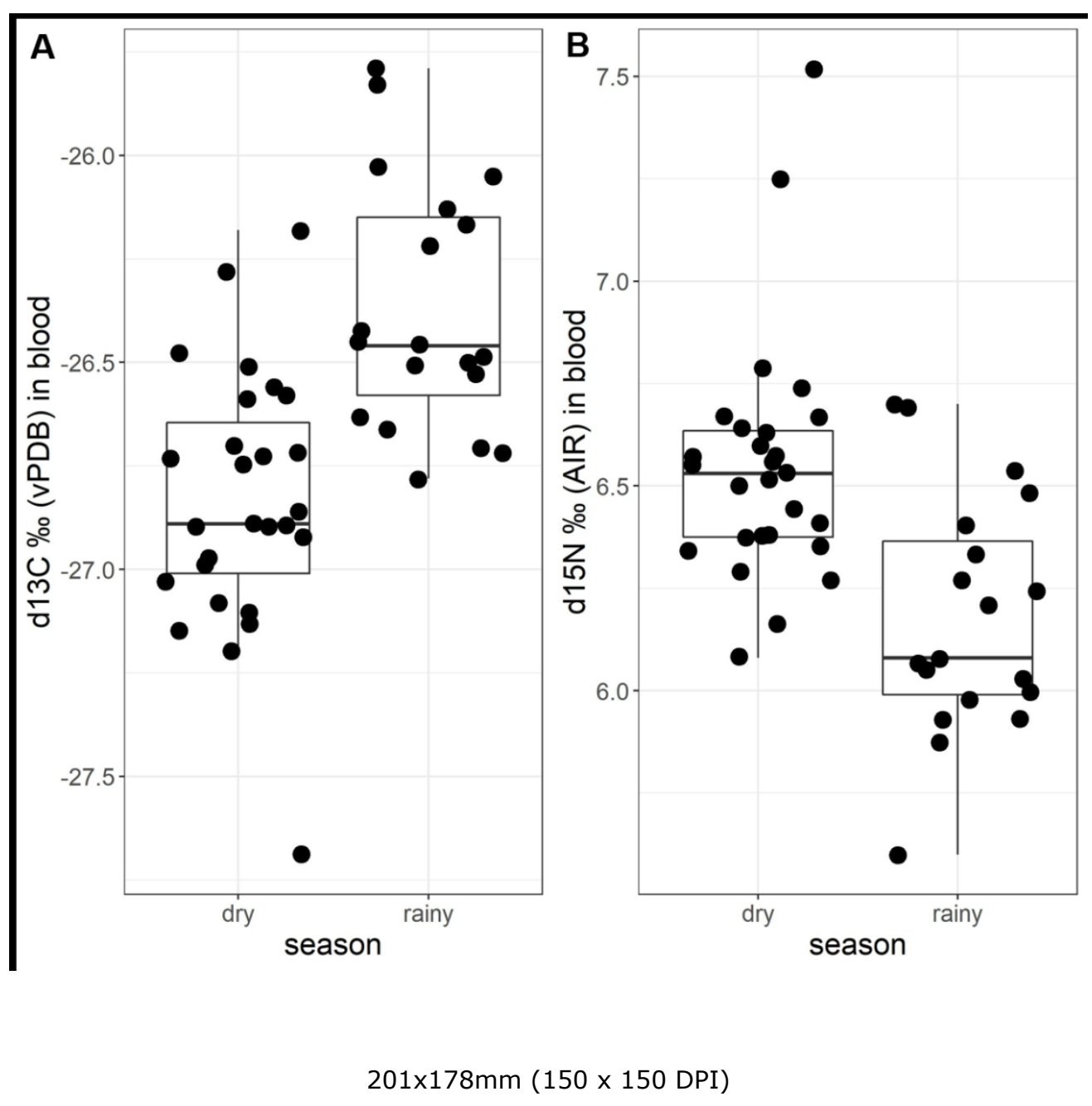

John Wiley \& Sons 

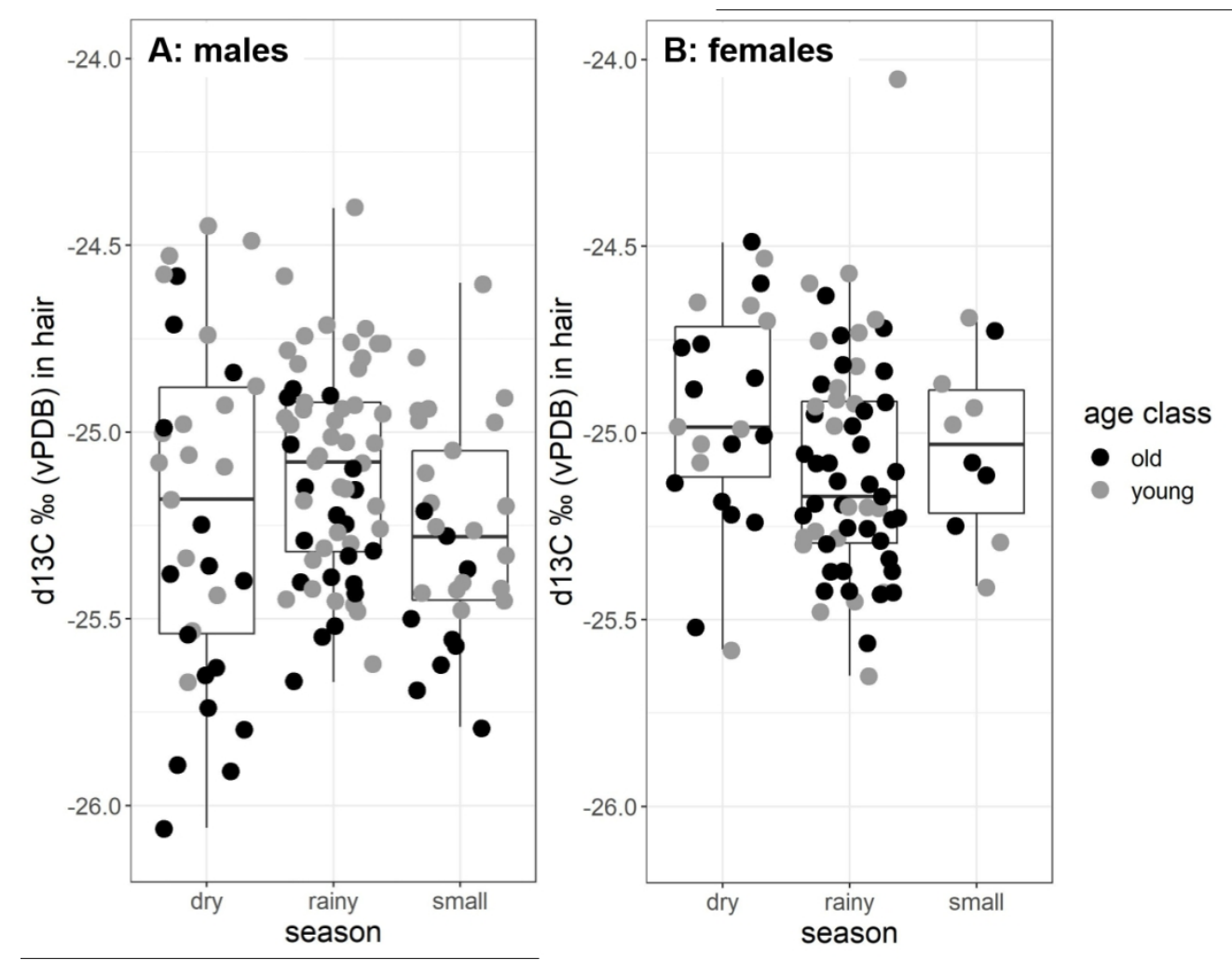

$227 \times 177 \mathrm{~mm}(150 \times 150 \mathrm{DPI})$

John Wiley \& Sons 


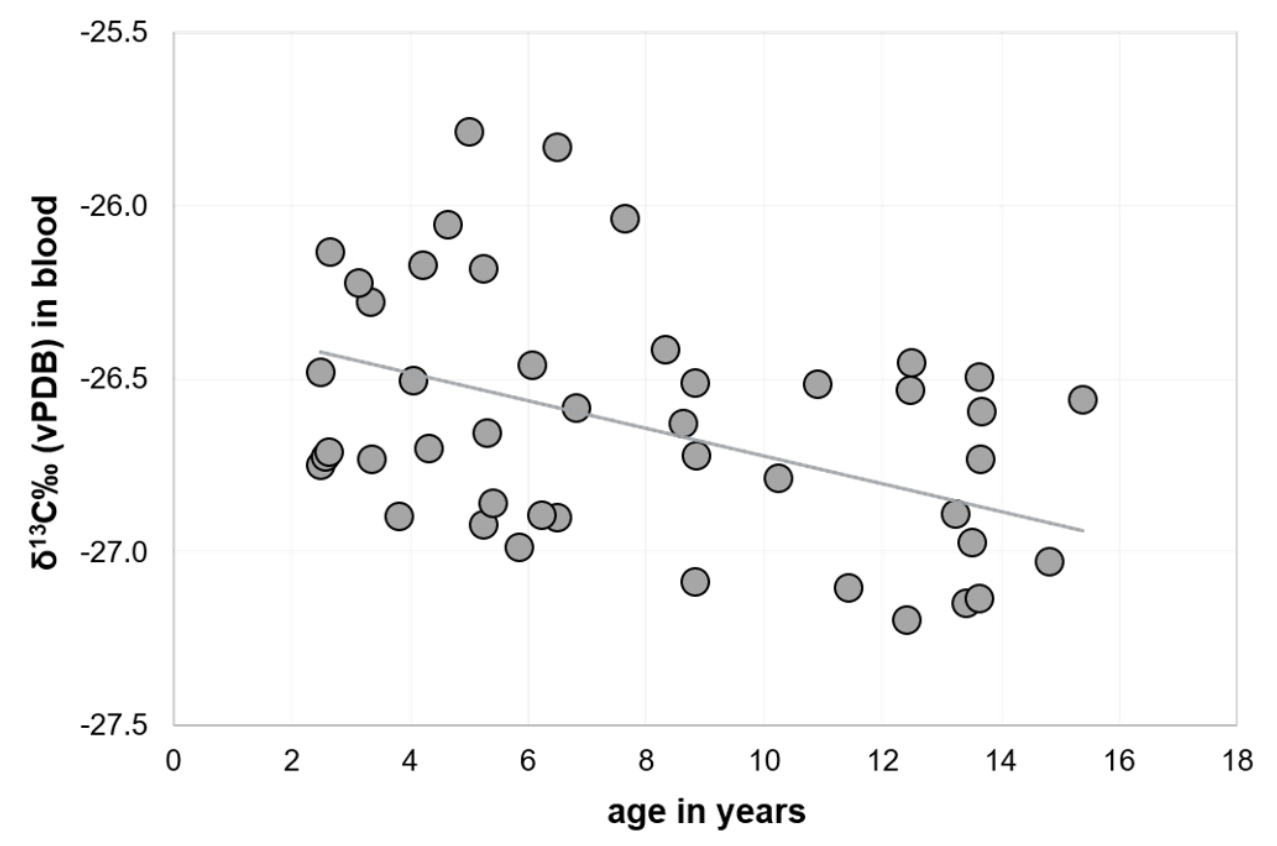

$178 \times 118 \mathrm{~mm}(150 \times 150 \mathrm{DPI})$

John Wiley \& Sons 


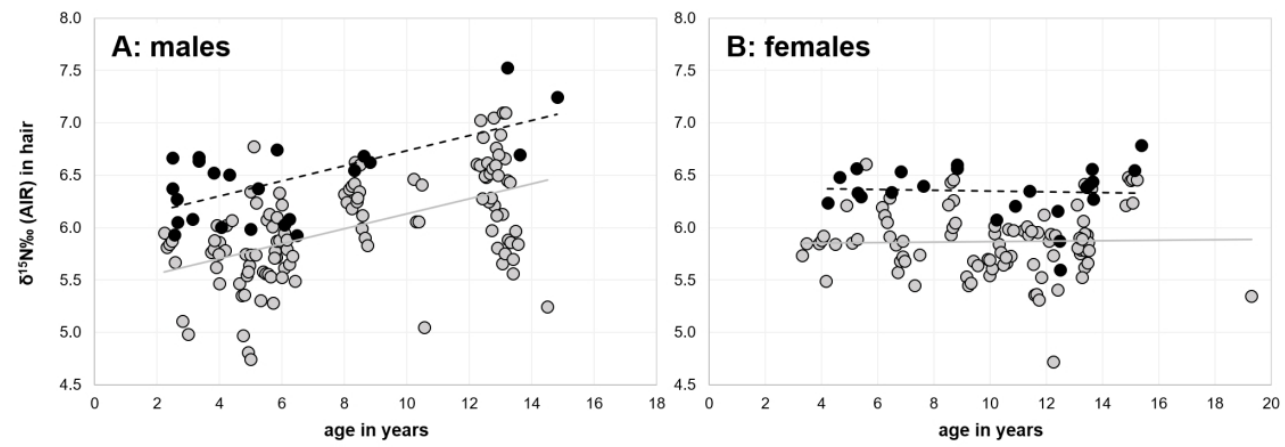

$353 \times 132 \mathrm{~mm}(150 \times 150 \mathrm{DPI})$ 
Supplementary information:

A

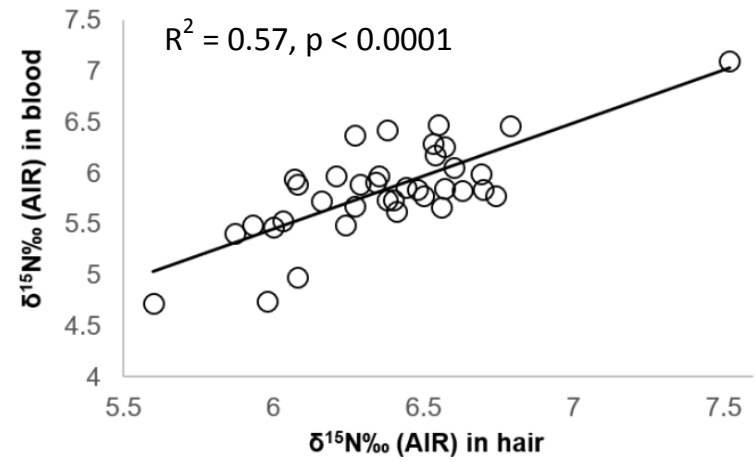

B

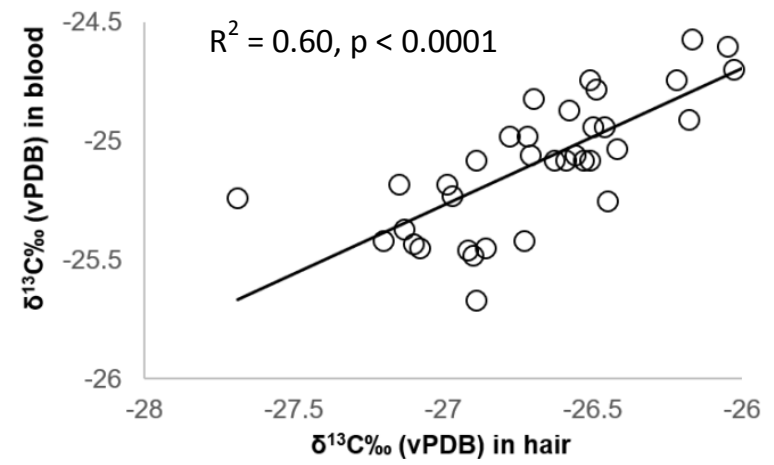

Figure S1: The $\delta^{13} \mathrm{C}(\mathbf{A})$ and $\delta^{15} \mathrm{~N}(\mathbf{B})$ values measured in hair sections and blood samples, each obtained from the same individuals calculated to be representing overlapping time windows $(n=37$ samples). Blood and hair isotope values are significantly correlated. 
Table S1: Stable isotopic values of a small selection of mandrill food items from Lékédi park. Insects and mushrooms were not determined to species level.

\begin{tabular}{lllcc} 
Species & Food category & Plant item & $\begin{array}{c}\boldsymbol{\delta}^{\mathbf{1 5}} \mathbf{N \%} \\
\text { AIR }\end{array}$ & $\begin{array}{c}\boldsymbol{\delta}^{\mathbf{1 3}} \mathbf{C \%} \\
\text { VPDB }\end{array}$ \\
\hline \hline Ants (unidentified) & fauna & - & 5.3 & -25.2 \\
Butterfly (unidentified) & fauna & - & 1.5 & -27.9 \\
Caterpillar (unidentified) & fauna & - & 6.7 & -26.4 \\
Mushroom 1 (unidentified) & na & - & 9.0 & -29.1 \\
Mushroom 2 (unidentified) & na & - & 3.0 & -32.1 \\
Mushroom 3 (unidentified) & na & - & 6.8 & -24.0 \\
Megaphrynium macrostachum & na & leaves/fruits & 4.4 & -31.5 \\
Smilax anceps & na & stems/seeds & 2.9 & -29.2 \\
Aframomum cf polyanthum & na & unknown & 2.3 & -32.8 \\
Croton sylvaticus & na & unknown & 5.1 & -29.7 \\
Geophila afzelii & na & unknown & 1.5 & -34.7 \\
Renealmia macrocolea & na & unknown & 3.6 & -33.1 \\
Uapaca guineensis & na & unknown & 4.0 & -29.0 \\
Dialium dinklagei & non-reproductive part & leaves & 6.4 & -32.1 \\
Lasianthus batangensis & non-reproductive part & leaves & 3.4 & -35.0 \\
Megaphrynium macrostachum & non-reproductive part & leaves & 11.6 & -29.9 \\
Nymphaea maculata & non-reproductive part & leaves & 6.6 & -28.7 \\
Psychotria stenostegia & non-reproductive part & stems/seeds & 1.8 & -35.4 \\
Cnestis corniculata & reproductive part & flowers & 5.4 & -31.6 \\
Psychotria gilletii & reproductive part & flowers & 3.8 & -28.9 \\
Psychotria stenostegia & reproductive part & fruits & 3.0 & -34.0 \\
Cnestis corniculata & reproductive part & seeds & 2.9 & -31.9 \\
Hylodendron gabunense & reproductive part & seeds & 4.4 & -26.7 \\
Psychotria gilletii & reproductive part & seeds & 2.5 & -28.9 \\
\hline
\end{tabular}




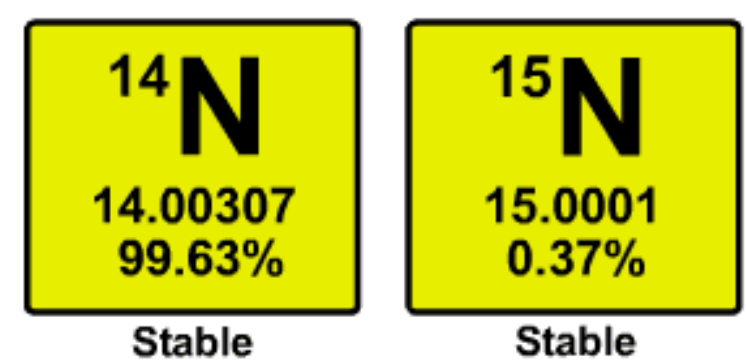

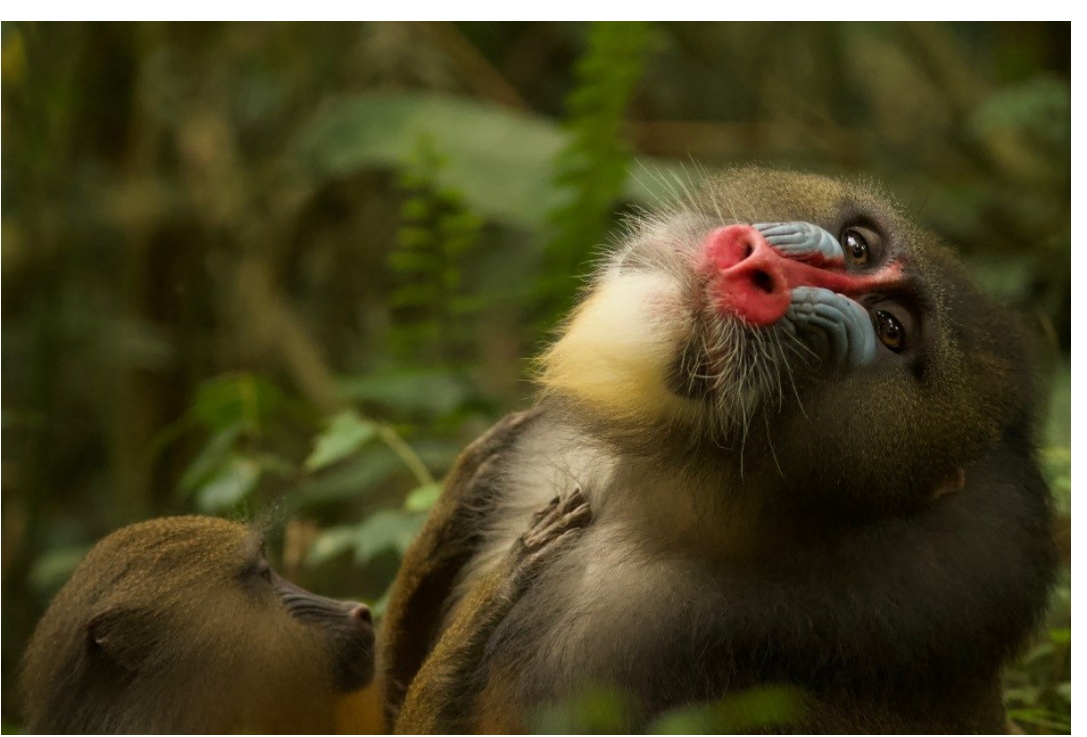

Photo-credit: Paul Amblard-Rambert 